nation of "Geological Survey" should be changed to "Geological and Natural History Survey." Some legislaters are fearful of the change. The important thing is to get an appropriation and start work. If a good start is made and the survey shows its desert, the change in title can come later.

In summarizing, I will but mention the few points $I$ have tried to emphasize in this paper:

1. With but seven states in the union supporting natural history surveys, the present condition of such work the country over is unsatisfactory.

2. Though efforts have been made to induce numerous states to establish natural history surveys, such efforts have been attended with but little success.

3. The probable cause of failure lies in the difficulty experienced by the promoters of such surveys in stating definite and important results that the survey will accomplish.

4. The suggestion is made that if the plea for a natural history survey propose a biogeographic regional survey whose reports can be used as guides for study by the schools, the proposal will be definite and the object such as to interest a large body of supporters.

5. To make these reports serve the purpose of scientific treatises as well as guides to the study of natural history and biogeography, special care must be used in the organization and presentation of the material in written form.

6. The successful preparation of local guides for the study of natural history, phytogeography and zoogeography will enable the survey to carry on other scientific work.

\section{F. C. Newcombe}

ANN ARBoR, MICH.
RECENT LEGISLATION AFFECTING EDUCATIONAL INSTITUTIONS IN KANSAS

THE state of Kansas, through its legislature which has just closed its biennial session, has finally decided to enter upon what may appeal to many as a doubtful experiment in educational administration, although it is hoped that a step forward has been taken. Essentially, the new arrangement consists in the application of the commission form of government, somewhat modified, to all of the state supported educational institutions.

Two years ago a bill to place the state university, agricultural college and normal school under one board of administration was passed. It will be recalled that Governor Stubbs at that time obtained the opinion of many prominent educators and administrators as to the probable success of the plan. Finding that there was almost a unanimous sentiment against this method of university administration, the governor finally vetoed the measure.

The present state officials were elected on a platform which pledged them to a reform measure which would place all higher educational institutions of the state under a single board. The motive for this change is a desire to secure a more efficient, and at the same time less expensive, administration, in that costly duplication of work in three separate institutions might be avoided without decreasing the efficiency or impairing the present high standards of all the institutions. In addition, it is believed that such a plan should lead, if properly carried out, to a better cooperation of all the parts of a complex educational system.

The act to bring about the centralization of authority in the management of the large state institutions was passed by the legislature, and signed by the governor on February 11. This measure includes the following institutions which are all placed under a single board of three members: The State University of Kansas, with the school of mines at Weir City; The Agricultural College at Manhattan, with its experiment stations located at Hays City, Dodge City, Garden City and Colby; the Normal School at Emporia, with the Manual Training Normal at Pittsburgh and the Nor- 
mal School at Hays City; the Kansas School for Deaf at Olathe, and the Kansas School for the Blind at Kansas City. Even this list may not be complete, as the branch schools have been scattered generously over the state. The members of the board are to receive a salary of $\$ 3,500$ each per year for their services.

An attempt to prevent political prejudices is found in the provisions which require that at least two political parties be represented, and that not more than one alumnus from any given institution may sit at the same time, on the board. Furthermore, the members must all be chosen from different congressional districts. Tenure of office as a member of the board is for four years, the appointments being made in such a way that the board can not be completely changed at any one time, except in ease of disqualification and suspension by the governor.

The board is given a large hand in the management of the affairs of the institutions, being given power to elect the presidents and treasurers, to appoint all professors, instructors, officers and employees; to fix the salaries which shall be paid, and to make all rules and regulations for rank and promotion of the faculty and employees. Apparently the whole administrative policy of the institutions is placed in their hands, the presidents being merely their executors and advisers. The management of all the property, execution of all trusts, the direction of the expenditure of all appropriations, and the investment of funds received by legacy and otherwise, are also vested in this single board.

The board, which will have its central office at Topeka, will assume charge on July 1, 1913. The commission is required to visit each institution at least monthly, and to make reports from time to time of the needs of the institutions which they control for the state.

The members of the commission appointed by Governor Hodges are Ex-governor E. W. Hoch, well known as editor and lecturer; Mrs. Cora G. Lewis, who has been prominent as an organizer of school employment bureaus, and who is well known for her literary attainments; and Edward T. Hackney, of Winfield, a graduate of the University of Kansas of 1895 , and a prominent lawyer. The governor seems to have succeeded admirably in a diffcult task. There is general agreement that the board is well fitted for the labors devolving upon it, and the friends of all the institutions are looking forward to a larger development under the new leadership. If an optimistic outlook makes for success in these matters, then the Kansas experiment should justify the high hopes entertained for the future.

Kansas has been exceedingly unfortunate in separating all of its educational institutions, and in pursuing the policy of scattering branch schools over the state for political reasons. It is impossible for the student who desires the advantages of the several schools to enjoy the privileges of all of them at once, as in the majority of states where at least agricultural college and university cooperate in education without duplication of forces and instructional staffs. In Kansas such a form of cooperation has been rendered impossible from the outset by the establishment of the institutions many miles apart. Wise foresight would have made the present conditions impossible. In no case have the agri. cultural colleges or state universities succeeded so well separately as when situated so that active cooperation and conjunction of forces are possible; and it remains to be seen whether the creation of a State Board of Administration of Educational Institutions can remedy a fundamental and irretrievable mistake in educational policy.

Those who have thus far guided the institutions will cooperate with the new board most heartily, and with singleness of purpose will seek to make the departure in administration successful from its inception. If carried out in the right spirit, this attempt at correlating and unifying the educational work of the state may result in very great advantage to all the interests concerned. The results of a somewhat different plan in Iowa have been far from satisfactory to any of the institutions. Of course, it is hoped and believed 
by the optimistic people of Kansas that similar results will not be obtained here.

The logical outcome of this new movement in Kansas would perhaps be a gradual merging of the interests of all the state schools, and the realization of a greater University of Kansas. The actual outcome will be watched with more than usual interest by every one who has at heart the problems of efficient and liberal university administration.

The University OF Kansas

Charles A. Shull

\section{SCIENTIFIC NOTES AND NEWS}

Dr. Hugh M. Sмiтh, deputy commissioner of fisheries, has been appointed United States fish commissioner.

The Chicago Section of the American Chemical Society has elected Dr. Leo H. Baekeland, of Yonkers, N. Y., to be the recipient of the Willard Gibbs medal, founded by William A. Converse. The first award was made in 1911 to Professor Svante Arrhenius, director of the Nobel Institute, at Stockholm, Sweden. The second medalist was Professor Theodore W. Richards, of Harvard University. The formal presentation of the Willard Gibbs medal will be made to Dr. Baekeland at the May meeting of the Chicago Section of the American Chemical Society. The jury of award which selected Dr. Baekeland comprised Professor Alexander Smith, Dr. W. R. Whitney, Dr. E. O. Franklin, Professor W. A. Noyes, Dr. J. D. Pennock, Professor G. B. Frankforter, Professor John H. Long, Professor Julius Stieglitz, Mr. William Brady, Mr. E. B. Bragg, Mr. S. T. Mather and Dr. G. Thurnauer.

The American Philosophical Society at its stated meeting on April 19 elected the following members: Dr. George F. Atkinson, professor of botany and head of the botanical department of Cornell University; Dr. Charles Edwin Bennett, professor of the Latin language and literature in Cornell University; Dr. John Henry Comstock, professor of ento- mology and invertebrate zoology in Cornell University and non-resident professor of entomology in Stanford University; Luther P. Eisenhart, professor of mathematics in Princeton University; George Washington Goethals, U.S.A., chief of engineers of the Panama Canal; William Crawford Gorgas, Assistant Surgeon General, U.S.A., member of the Isthmian Canal Commission; Dr. Ross Granville Harrison, professor of comparative anatomy, Yale University; George Augustus Hulett, professor of physical chemistry in Princeton University; Dr. Clarence Erwin McClung, professor of zoology, University of Pennsylvania; John Dyneley Prince, professor of Semitic languages in Columbia University and president of the House of Representatives of New Jersey; Dr. Samuel Rea, president of the Pennsylvania Railroad Company; Dr. Henry Norris Russell, professor of astronomy at Princeton University; Witmer Stone, curator of ornithology of the Philadelphia Academy of Natural Sciences. Three foreign members were elected as follows: Sir Arthur John Evans, keeper of the Ashmolean Museum, Oxford; Sir Joseph Larmor, Lucasian professor of mathematics at Cambridge; and Dr. Arthur Schuster, professor of physics at the University of Manchester.

THE Lobachersky prize of the Academy of Sciences of Kasan has been awarded to Professor F. Schur, of the University of Strassburg, for his researches in the foundations of geometry.

The University of Edinburgh will confer the degree of LL.D. on the Hon. James Wilson, lately secretary of agriculture of the United States.

Dr. Alexis Carrel and Dr. Hideyo Noguchi, of the Rockefeller Institute, Dr. H. M. Biggs and Dr. William H. Park, of the New York Department of Health, and Dr. John W. Brannan, of Bellevue and allied hospitals, have been made knights of the Royal Order of Isabella the Catholic by King Alfonso of Spain.

Dr. Thomas N. Carver, of Harvard University, has been appointed by Secretary 